越冬アユから分離された 細菌性冷水病原因菌 Flavobacterium psychrophilum

宮崎統五

（2008年 5 月14日受付）

\section{Flavobacterium psychrophilum Isolated from Overwintering Ayu Plecoglossus altivelis}

\author{
Tougo Miyazaki \\ Fisheries Research Institute, Toyama Prefecture \\ Agricultural, Forestry and Fisheries Research \\ Center, Namerikawa, Toyama 936-8536, \\ Japan
}

(Received May 14, 2008)

\begin{abstract}
Overwintering ayu Plecoglossus altivelis $(\mathrm{n}=23)$ were captured in Sho-river, Toyama Prefecture in April, 2007, and kept under a crowded condition (120 $\mathrm{g}$ fish/L). When the fish became moribund or dead, bacteria were isolated from the kidney of the fish using a modified Cytophaga agar plate, and the isolates were examined by the PCR-RFLP method using primers targeting gyrA, gyrB and $P P I C$ genes of Flavobacterium psychrophilum. The isolates obtained from nine individuals of the fish were identified as $F$. psychrophilum and classified into two genotypes of $A / R / Q R$ and $A / S / Q R$. An isolate from each genotype was virulent to ayu. These results showed that overwintering ayu carry virulent $F$. psychrophilum, suggesting a source of infection for newcomers of ayu in this spring.
\end{abstract}

Key words: Flavobacterium psychrophilum, Plecoglossus altivelis, carrier, bacterial cold water disease

アユ Plecoglossus altivelis の細菌性冷水病は，養殖場 だけでなく，河川においても毎年発生がみられている。 近年では，消毒された受精卵 ${ }^{1)}$ から生産されたアユが放 流されているにもかかわらず，河川内では細菌性冷水病 に罹患したアユが毎年みられていることから，病原体

\footnotetext{
富山県農林水産総合技術センター水産研究所

* Corresponding author

E-mail: Togo.miyazaki@pref.toyama.Ig.jp
}

キャリアが周年河川内に存在していることが疑われて いる。アユの多くは秋に産卵して死亡するため，冬 期には河川でほとんど生息していないが，冬期の河 川水および藻類から細菌性冷水病原因菌 Flavobacterium psychrophilumの遺伝子が検出されている ${ }^{2,3)}$ 。しかし， 現在までのところ，冬期に河川環境や魚類から F. Psychrophilum が分離されたとの報告はない。

アユのうちの一部は未成熟のまま越冬する個体（越冬 アユ）があることが知られており4，これら越冬アユが F. psychrophilumのキャリアとして次世代のアユへの感 染源になっている可能性が考えられる。本試験では，4 月中旬に河川で越冬アユを採集し，それらからF. psychrophilumの分離を試み，分離菌のアユに対する病 原性を調べた。

\section{材料および方法}

富山県内を流下する庄川の河口から上流約 $10 \mathrm{~km}$ の河 川敷に， $10^{\circ} \mathrm{C}$ の伏流水が湧出する水域（末端は庄川本流 へ合流する）があり，そこで生息していたアユ23尾（平 均体重 \pm 標準偏差：10.5 $2.5 \mathrm{~g}$, 体重の範囲：6.7 $16.1 \mathrm{~g}$ ）を採集した（河川採集アユ）。アユの採集は，種 苗放流が行われる前の2007年 4 月18日に，エレクトリッ クショッカー（Smith-Root, Inc., USA）を用いて行った。 河川採集アユは，塩化ベンザルコニウムで消毒済の容器 に収容し，通気しながら富山県水産試験場へ搬送した。 その後, 平均水温 $13^{\circ} \mathrm{C}$ の地下水をかけ流した $2 \mathrm{~L}$ の水槽 に収容し，高密度（120 g 体重/L), 無給慨で飼育した。 飼育に用いた地下水にF.psychrophilum が混入していな いことを確認するため，あらかじめ F. psychrophilum フ リーであることを確認したアユ60尾（平均体重士標準偏 差： $5.4 \pm 0.6 \mathrm{~g} ）$ を $3 \mathrm{~L}$ の水槽に収容し，同様の条件で飼 育して対照区とした。

河川採集アユは，高密度飼育下で23日以内に全てが衰 弱または死亡した。これらのアユが衰弱または死亡した 時点で取上げ，腎臓の組織片を採取して改変サイト ファーガ寒天平板培地 ${ }^{5)}$ に塗沫し， $17^{\circ} \mathrm{C} て ゙ 48 \sim 72$ 時間 培養した。培地上で黄色集落が発育した場合には，河川 採集アユ 1 尾当り最大 8 集落を釣菌した。分離菌につい て，F. Psychrophilumのジャイレース B 遺伝子 ${ }^{6)}$ ， ジャ イレース $\mathrm{A}$ 遺伝子 ${ }^{7)}$ および Peptidyl-prolyl cis-trans isomerase C (PPIC) 遺伝子 ${ }^{8)}$ を標的としたPCR を行 い，全てのPCR で陽性の場合に分離菌を F. psychrophilum であると判定した。さらに，分離菌がF. Psychrophilum と判定された場合, ジャイレースB遺伝子, ジャイレー ス $\mathrm{A}$ 遺伝子および PPIC 遺伝子それぞれの PCR 産物につ いて，制限酵素 Rsal，Mph1103l および Hinfl を用いた RFLPにより遺伝子型を判定した。

河川採集アユから分離された F. psychrophilum 集落の 
うち，ジャイレース B 遺伝子とRsal を組み合わせた PCR-RFLP 検査で遺伝子型がR 型および $S$ 型と判定され た 1 株ずつを用い，病原性試験を行った。それぞれの菌 株 1 白金耳を $50 \mathrm{~mL}$ の改変サイトファーガ液体培地に 別々に接種し, $17^{\circ} \mathrm{C}$ で 1 昼夜振盪培養した。培養液の菌 濃度は，R 型株は $5.4 \times 10^{6} \mathrm{CFU} / \mathrm{mL}, \mathrm{S}$ 型株は $2.9 \times$ $10^{7} \mathrm{CFU} / \mathrm{mL}$ であった。 $\mathrm{R}$ 型および $\mathrm{S}$ 型の培養液それぞ れを飼育水 $4.5 \mathrm{~L}$ で希釈し, F. psychrophilum フリーの アユ20尾（平均体重士標準偏差：10.3 $22.2 \mathrm{~g}$ ) ずつを収 容し，通気しながら 7 時間放置した（以下 R 区および 区)。対照区では，菌を接種していない改変サイトファー ガ液体培地 $50 \mathrm{~mL}$ を $4.5 \mathrm{~L}$ の飼育水に加え, アユ20尾を 収容して 7 時間通気した。その後, 各区の水槽に水温約 $13^{\circ} \mathrm{C}$ の地下水をかけ流し，12日間無給慨で飼育した。飼 育期間中に死亡したアユについては，前述した方法で細 菌培養を行った。培地上に黄色集落が発育した場合には, 数集落を集菌し，ジャイレース B 遺伝子小よび Rsal を 組み合わせた PCR-RFLP 検査を行って遺伝子型を調心゙ た。

飼育期間中の R区およびS区の死亡率を対照区と比較 し，Fisher 法によって有意差を検定した。

\section{結果}

河川採集アユ23尾のうち16尾から黄色集落が分離さ れ，このうち 9 尾から分離された集落が F. psychrophilum と判定された。同じ地下水を用いて飼育した対照区では, 4 尾のアユから黄色集落が分離されたが，いずれもF. psychrophilumではないと判定された。F. Psychrophilum が分離された河川採集アユ 9 尾のうち 5 尾からの分離菌 は全て $A / R / Q R$ の遺伝子型であったが，残り 4 尾からは $A / R / Q R$ および $A / S / Q R$ の遺伝子型の菌が分離された。

病原性試験においては，対照区では死亡魚はみられな かったが，R区およびS区では試験開始 3 日後から死亡 が始まり，試験期間中にR区で20尾中15尾，S区で20尾 中17尾の供試魚が死亡した。各区の死亡魚の腎臓を用い
た再分離では，R区の死亡魚15尾のうちの11尾（供試尾 数に対する割合：55\%）およびS区の死亡魚17尾のうち の15尾（供試尾数に対する割合：75\%）で黄色集落の発 育がみられ，これらの菌のジャイレースB遺伝子による PCR 検査結果は全て陽性であった（Table 1)。R区およ びS区の死亡率は対照区のそれより有意 $(p<0.001)$ に 高かった。また，R区の供試魚からの集落の遺伝子型は 全てR型であり，S区のそれは全てS型であった。

\section{考察}

高密度飼育中に衰弱または死亡した河川採集アユの 腎臟からF. psychrophilum が分離された一方，同じ 地下水を用いて同様に飼育した対照区のアユからは $F$. psychrophilum が検出されなかったことから, 分離され た F. psychrophilum は飼育水を介して侵入したものでは なく，採集の時点でアユが保有していたものに由来する と考えられる。河川採集アユ 9 尾から F. psychrophilum が分離されたが，これらのアユは高密度飼育下で発症し たことから，採集時点で 9 尾全てが保菌していたとは言 えないが，少なくとも一部のアユが保菌していたことは 間違いない。熊谷・縄田*1は，F. Psychrophilum が検出 限界以下のレベルで感染しているアユを高密度飼育する ことにより, 体内の菌濃度が検出限界以上に増加するこ とを報告している。本試験では，河川採集アユの飼育密 度を体重 $120 \mathrm{~g} / \mathrm{L}$ 飼育水容積とし, 通常のア工飼育に比 べて10倍以上の高密度としたところ，それらから F. psychrophilumが分離されたことから，過密飼育によっ てF. Psychrophilum が体内で増殖し, 本試験で用いた方 法で検出できる菌数まで増加したと思われる。

田子 ${ }^{9)}$ は, 富山県内に抢ける 4 月から 6 月の遡上アユ の生態を 4 力年にわたって調査し，遡上が始まるのは 4 月上旬であること，遡上魚の体重のモードは4.0から 6.6 $\mathrm{g}$ にあることおよび体重の最大值は $7.2 \mathrm{~g}$ であったことを 報告している。本調查で採集を行った時点は，すでに海 産アユが遡上を開始している時期であり，海産アユが採

Table 1. Result of a challenge test using Flavobacterium psychrophilum isolated from overwintering ayu.

\begin{tabular}{lcccc}
\hline $\begin{array}{l}\text { Gennotype of } \\
\text { F. psychrophilum }\end{array}$ & $\begin{array}{l}\text { Number of } \\
\text { ayu } \\
\text { challenged }\end{array}$ & $\begin{array}{l}\text { Number of } \\
\text { ayu died }\end{array}$ & $\begin{array}{l}\text { Number of ayu died of } \\
\text { bacterial cold water } \\
\text { disease* }\end{array}$ & $\begin{array}{l}\text { Significance of mortality } \\
\text { caused by bacterial cold } \\
\text { water disease compared } \\
\text { with control (p) }\end{array}$ \\
\hline A/R/QR & 20 & 15 & 11 & $<0.001$ \\
A/S/QR & 20 & 17 & 15 & $<0.001$ \\
Control & 20 & 0 & 0 & - \\
\hline
\end{tabular}

\footnotetext{
* F. psychrophilum was re-isolated from dead fish.
}

\footnotetext{
*1 熊谷 明・縄田 暁 (2006) : 宮城水試研究成果要旨集, 3031.

*2 村木誠一・田子泰彦 (2004)：富山水試研報，15，11-18.
} 
集地点付近まで到達していた可能性があった。しかし， 河川採集アユの体重は $6.7 \mathrm{~g}$ から $16.1 \mathrm{~g}$ の範囲で，田 子 $^{9)}$ の報告より大型であり，23尾のうち21尾が $7.2 \mathrm{~g}$ 以 上であったことから，河川採集アユのほとんどまたは全 てが越冬アユであったと考えられた。また，村木・田 子*2 は，2001年から2002年に富山県内で採集したアユ降 下仔魚715尾の PCR 検査を行い, F. psychrophilum の遺 伝子は全く検出されなかったと報告していること，河口 付近で採集した遡上期のアユ120尾の体表または腎臓から は F. psychrophilum が分離されなかったこと（未発表）， F. psychrophilum は $2 \%$ 以上の塩化ナトリウム存在下で

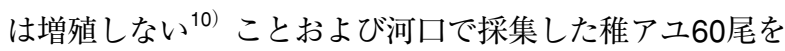
高密度飼育したところ，衰弱魚または死亡魚の腎臓から F. psychrophilum は検出されなかったこと（未発表）か ら，海産稚アユが F. psychrophilum を保有している可能 性は低く, 本試験で分離されたF. psychrophilum は, 越 冬アユが前年から保有していたものである可能性が高い と考えられる。

本試験では，越冬アユから $\mathrm{A} / \mathrm{R} / \mathrm{QR}$ および $\mathrm{A} / \mathrm{S} / \mathrm{QR}$ の 遺伝子型の F. psychrophilum が検出された。また，A 遺 伝子型の菌はアユに対する病原性が高いことが知られて おり，予想どおりにそれぞれの遺伝子型の代表株はアユ に病原性を示した。A 遺伝子型の F. Psychrophilum が河 川に常在するアユ以外の魚種から検出されることは稀6,11)
であることおよび今回の結果から，越冬アユが河川にお ける A 型 F. psychrophilumのキャリアとして次世代への 感染源となると考えられる。

\section{謝 辞}

本研究は, 独立行政法人水産総合研究センターからの 健全な内水面生態系復元等推進委託事業の研究費によっ て実施されました。記して御礼申し上げます。

\section{文献}

1) Kumagai, A., C. Nakayasu and N. Oseko (2004): Fish Pathol., 39, 183-187. 2) 網田健次郎 - 星野正邦 - 本間智晴 · 若林久嗣 (2000) : 魚病研究，35，193-197. 3） Izumi, S., H. Fujii and F. Aranishi (2005)：J. Fish Dis., 28, 559-564. 4) 荒 賀忠一 (1984)：「日本産魚類大眓鑑，益田一・尼岡邦夫 - 荒 賀忠一 -上野輝彌 - 吉野哲夫編」, 東海大学出版会, 東京, pp. 33. 5) Wakabayashi, H. and S. Egusa (1974): Fish. Sci. 40, 751-757. 6) Izumi, S., F. Aranishi and H. Wakabayashi (2003): Dis. Aquat. Org., 56, 207-214. 7) Izumi, S., S. Ouchi, T. Kuge, H. Arai, T. Mito, H. Fujii, F. Aranishi, and A. Shimizu (2007)：J. Fish Dis., 30, 141-147. 8) 吉浦康寿 . 釜石 隆 - 中易千早 - 乙竹 充 (2006) : 魚病研究, 41, 6771. 9）田子泰彦（2002）：日水誌，68，554-563. 10）若林 久嗣 (2004): 「魚介類の感染症 - 寄生虫病, 江草周三監, 若林 久嗣・室賀清邦編」, 恒星社厚生閣, 東京, pp. 177-183. 11) 新井 肇・藤田雅弘・鈴木究真・片桐孝之 - 久下敏広 (2006)： 水産増殖，54，575-576. 